\title{
Cognitive behavioural therapy for major psychiatric disorder: does it really work? A meta-analytical review of well-controlled trials
}

\author{
D. Lynch ${ }^{1}$, K. R. Laws ${ }^{2}$ and P. J. McKenna ${ }^{3,4 *}$ \\ ${ }^{1}$ Stobhill Hospital, Glasgow, UK \\ ${ }^{2}$ School of Psychology, University of Hertfordshire, Hatfield, UK \\ ${ }^{3}$ Benito Menni CASM, Barcelona, Spain \\ ${ }^{4}$ CIBERSAM, Spain
}

Background. Although cognitive behavioural therapy (CBT) is claimed to be effective in schizophrenia, major depression and bipolar disorder, there have been negative findings in well-conducted studies and meta-analyses have not fully considered the potential influence of blindness or the use of control interventions.

Method. We pooled data from published trials of CBT in schizophrenia, major depression and bipolar disorder that used controls for non-specific effects of intervention. Trials of effectiveness against relapse were also pooled, including those that compared CBT to treatment as usual (TAU). Blinding was examined as a moderating factor.

Results. CBT was not effective in reducing symptoms in schizophrenia or in preventing relapse. CBT was effective in reducing symptoms in major depression, although the effect size was small, and in reducing relapse. CBT was ineffective in reducing relapse in bipolar disorder.

Conclusions. CBT is no better than non-specific control interventions in the treatment of schizophrenia and does not reduce relapse rates. It is effective in major depression but the size of the effect is small in treatment studies. On present evidence CBT is not an effective treatment strategy for prevention of relapse in bipolar disorder.

Received 20 August 2008; Revised 11 March 2009; Accepted 18 March 2009; First published online 29 May 2009

Key words: Bipolar disorder, cognitive therapy, depression, schizophrenia.

\section{Introduction}

Cognitive behavioural therapy (CBT) has been widely adopted by psychiatry in recent years, but its increase in use in the severe disorders of schizophrenia, major depression and bipolar disorder is particularly noteworthy. This is because it challenges what has, until recently, been a dominance of biological approaches to these disorders. Thus, although contemporary accounts of schizophrenia (e.g. Picchioni \& Murray, 2007) emphasize biological factors in its aetiology and consider neuroleptic drugs to be the mainstay of treatment, official UK treatment guidelines from the National Institute for Clinical Excellence (NICE) also state that psychological interventions are indispensable and that CBT should be offered to all patients (NICE, 2003, 2009). Psychological factors may loom

* Address for correspondence: Dr P. J. McKenna, Benito Menni Complex Assistencial en Salut Mental, Germanes Hospitalàries del Sagrat Cor de Jesús, C/Doctor Antoni Pujades 38-C, 08830 Sant Boi de Llobregat, Barcelona, Spain.

(Email : mckennapeter1@googlemail.com) larger in the aetiology of major affective disorder, but when it comes to treatment, the emphasis in the literature, particularly in bipolar disorder, has once again been firmly on pharmacotherapy. Attitudes may be changing here too, however. References to the effectiveness of CBT are pervasive in the UK depression treatment guideline (NICE, 2004); a government initiative is under way in the UK to provide CBT for depression and anxiety in 250 dedicated therapy centres (Layard, 2006); and CBT is being advocated for relapse prevention in bipolar disorder (e.g. Scott \& Colom, 2005; Basco \& Rush, 2007).

Nevertheless, a cursory look at the literature reveals well-conducted trials where CBT has had negative findings in all three disorders. For example, large-scale trials of CBT in schizophrenia have failed to find significant advantages over befriending (Sensky et al. 2000) or supportive counselling (Lewis et al. 2002). In depression, the National Institute of Mental Health (NIMH) study of brief psychotherapeutic interventions found only marginal evidence for the effectiveness of interpersonal psychotherapy and none for 
cognitive therapy (Elkin et al. 1989). A recent large trial of CBT for prevention of relapse in bipolar disorder found no advantage over treatment as usual (TAU) (Scott et al. 2006). In fact, the perceived efficacy of CBT in all three disorders seems to rest principally on metaanalysis, where it has been concluded, for example, that: 'The positive results ... can therefore be taken as confirming the promise of cognitive behavioural treatment in schizophrenia' (Pilling et al. 2002); 'cognitive therapy has been demonstrated effective in patients with mild or moderate depression and its effects exceed those of antidepressants' (Gloaguen et al. 1998); and 'the use of psychological therapies as an adjunct to medication [in bipolar disorder] is likely to be clinically and cost effective' (Scott et al. 2007).

A feature of these and other meta-analyses, however, is the lack of consideration they have given to bias caused by lack of blinding and the failure to use a control intervention. For example, out of seven metaanalytical reviews of CBT for schizophrenia (Gould et al. 2001; Rector \& Beck, 2001; Pilling et al. 2002; Jones et al. 2004; Tarrier \& Wykes, 2004 ; Zimmermann et al. 2005; Wykes et al. 2008), only two (Zimmermann et al. 2005; Wykes et al. 2008) examined the influence of blindness on effect size, and neither of these attempted to establish the treatment's effectiveness in trials that used both blinding and a control intervention. Nor was blindness addressed in either of the two benchmark meta-analyses of CBT for depression (Gloaguen et al. 1998; Churchill et al. 2001). The way in which CBT was compared against other psychological interventions in Gloaguen et al.'s (1998) meta-analysis has also been criticized (Parker et al. 2003).

Noting that there is increasing evidence that inadequate quality of trials can translate into biased findings of systematic reviews in health care, Jüni et al. (2001) recommended that the influence of study quality should be examined routinely. They also argued that it is preferable to do this by examining the influence of key components of methodological quality individually rather than by means of summary scores from quality scales, which are problematic for several reasons. This meta-analysis therefore examines the effectiveness of CBT in studies that have attempted to guard against two of the most familiar and important sources of bias in treatment trials, lack of blinding and failure to use a control intervention.

\section{Method}

We included studies that examined the effectiveness of CBT in adults (i.e. not adolescents or elderly subjects) meeting any diagnostic criteria for schizophrenia (some of which also allowed patients with schizoaffective disorder and delusional disorder), major depression or bipolar disorder. CBT was defined as an intervention whose core elements include the recipient establishing links between their thoughts, feelings and actions and target symptoms; correcting misperceptions, irrational beliefs and reasoning biases related to these target symptoms, involving monitoring of one's own thoughts, feelings and behaviours with respect to the symptom; and/or the promotion of alternative ways of coping with target symptoms.

The studies were required to use a control intervention that the study investigators either explicitly considered not to have specific therapeutic effects or which might reasonably be regarded as lacking these (e.g. supportive therapy, psycho-education, relaxation). We also included studies comparing CBT to pill placebo (which have only been carried out in major depression). Blindness of evaluations was not specified as a requirement for inclusion, but was examined as a moderator variable. In keeping with the general approach of meta-analysing methodologically rigorous trials, we did not include studies with small sample sizes ( $<10$ participants in either group) or studies that were identified by the authors as pilot studies. Excluded studies are given as Supplementary material (available in the online version of the paper).

We also meta-analysed studies of CBT for prevention of relapse, even though many of these used TAU as the comparison condition rather than a control intervention. This was on grounds that $(a)$ relapse is a relatively objective outcome measure that should be robust to the effects of subject and observer bias; and (b) relapse prevention has been a major focus of studies of CBT in depression and constitutes the only type of study that has been carried out in bipolar disorder. Nevertheless, we also examined the use of TAU or a control intervention as a moderator variable, where possible, in these studies. To be included, studies had to use a symptomatic definition of relapse, rather than simply equating this with rehospitalization, and had to define relapse according to predetermined criteria.

Studies were searched using existing comprehensive meta-analyses of CBT for schizophrenia (Jones et al. 2004), depression (Gloaguen et al. 1998; Churchill et al. 2001; Vittengl et al. 2007) and bipolar disorder (Scott et al. 2007), supplemented by electronic searches of the literature (Medline, EMBASE and PsycINFO). For the electronic search, we chose inception dates of 5 years before the publication of the earliest of the above meta-analyses, which would have captured earlier studies. The search was conducted up to the end of January 2009. Review articles and the reference lists of all obtained papers were checked, as were research databases for trials. Only published studies were included. There were no restrictions on year of 


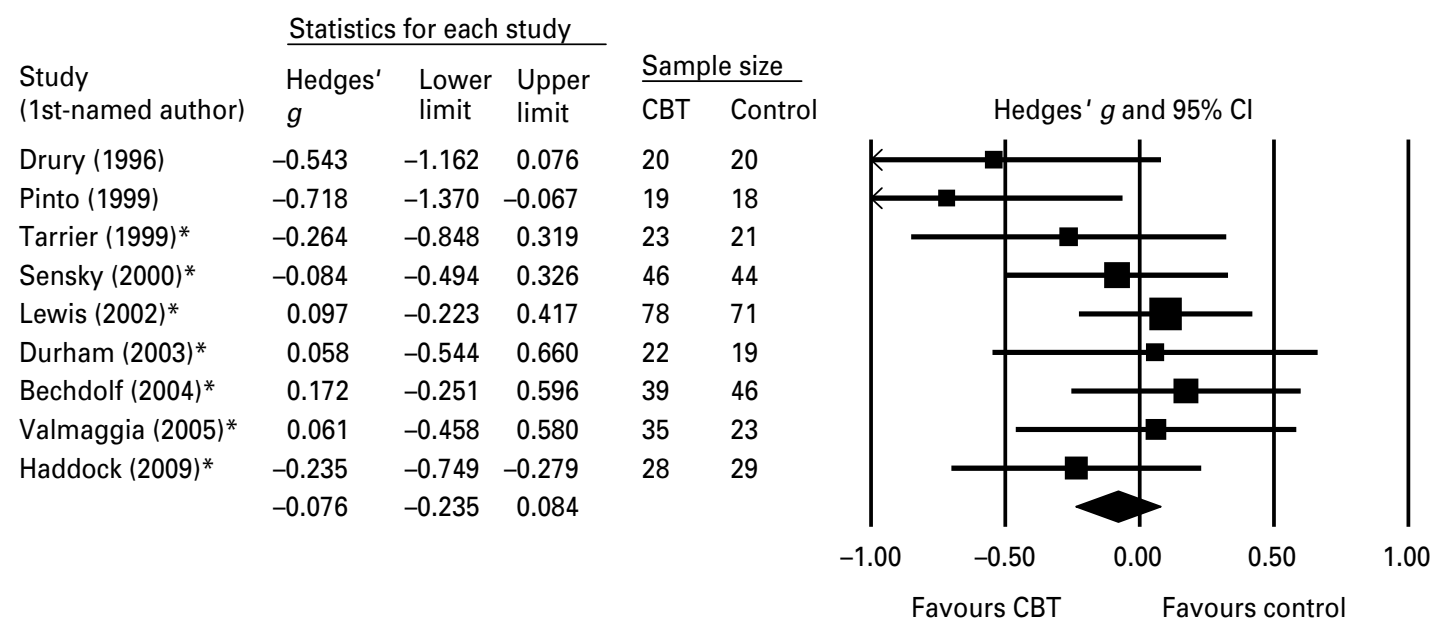

Fig. 1. Studies of the effectiveness of cognitive behavioural therapy (CBT) against symptoms in schizophrenia (* indicates blind study).

publication or language. Tables A1 and A2 in the Appendix provide details on the included studies.

Data were synthesized using standard metaanalytical techniques. Studies comparing the effect of CBT against a control intervention were pooled from continuous measures (i.e. symptom scores) using an effect size measure, Cohen's $d$ (Hedges' correction was used). The end-point was the end of the acute treatment phase as defined by the investigators. In line with common meta-analytical practice, effect sizes obtained from a range of different symptom rating scales were pooled; we did not attempt to carry out separate analyses for the different scales, unless there were fundamental conceptual differences between them (e.g. self-rated versus observer-rated). Odds ratios (ORs) were calculated for relapse rates. Fixedeffects analysis was used in both cases (random effects analyses gave similar results). Intention-to-treat analysis was used if relevant data were available (typically in relapse studies) or, if not, on the numbers remaining at the end of the study period. Two of the investigators extracted effect sizes and ORs by consensus. All results were checked twice. Heterogeneity was assessed by means of the Q-statistic.

\section{Results}

\section{Schizophrenia}

\section{Effectiveness on symptoms}

Nine trials were found. We excluded two studies of first-episode psychosis (Jackson et al. 2008; Lecomte et al. 2008) because they both contained a high proportion of patients $(>20 \%)$ with affective psychotic diagnoses. The studies were carried out on both acute and chronic patients and the period of treatment ranged from 5 weeks to 9 months. The control interventions used were supportive counselling/supportive therapy $(n=5)$, befriending $(n=1)$, group psycho-education $(n=1)$, recreational therapy $(n=1)$ and social activity therapy $(n=1)$. Two were open studies and seven were carried out under blind conditions. Several studies did not provide overall symptom scores but instead gave separate scores for positive and negative symptoms (and sometimes disorganization or general psychopathology). To maximize the number of usable studies, therefore, a combined effect size for all symptoms for each study was first calculated by averaging the effect sizes for these symptoms (this was done using the individual effect sizes and standard errors, using a random effects model and testing for homogeneity in each case). Effects on positive and negative symptoms were then examined separately.

The findings are shown in Fig. 1. The pooled effect size was -0.08 [95\% confidence interval $(\mathrm{CI})-0.23$ to $+0.08, p=0.34]$ (the negative sign favours CBT). The studies were not significantly heterogeneous $[Q(8)=$ 9.28, $p=0.32$ ]. As Fig. 1 suggests, the two non-blind studies had a significantly larger pooled effect size than the seven blind studies $(-0.63$ v. 0.00) $[\mathrm{QB}(1)=$ $6.38, p=0.01]$. Dividing studies into those carried out on acute patients $(n=1)$, mixed or unspecified patients $(n=6)$ and chronic patients $(n=2)$ did not reveal differences [effect size $+0.10,-0.17$ and -0.04 respectively, $\mathrm{QB}(2)=1.82, p=0.40]$. The overall effect size was increased only slightly by excluding the single study that used a group therapy form of CBT (Bechdolf et al. 2004) (effect size for eight studies $=-0.11,95 \% \mathrm{CI}$ -0.29 to $+0.06, p=0.19$ ).

Eight studies reported findings for positive symptoms and seven for negative symptoms. The pooled 


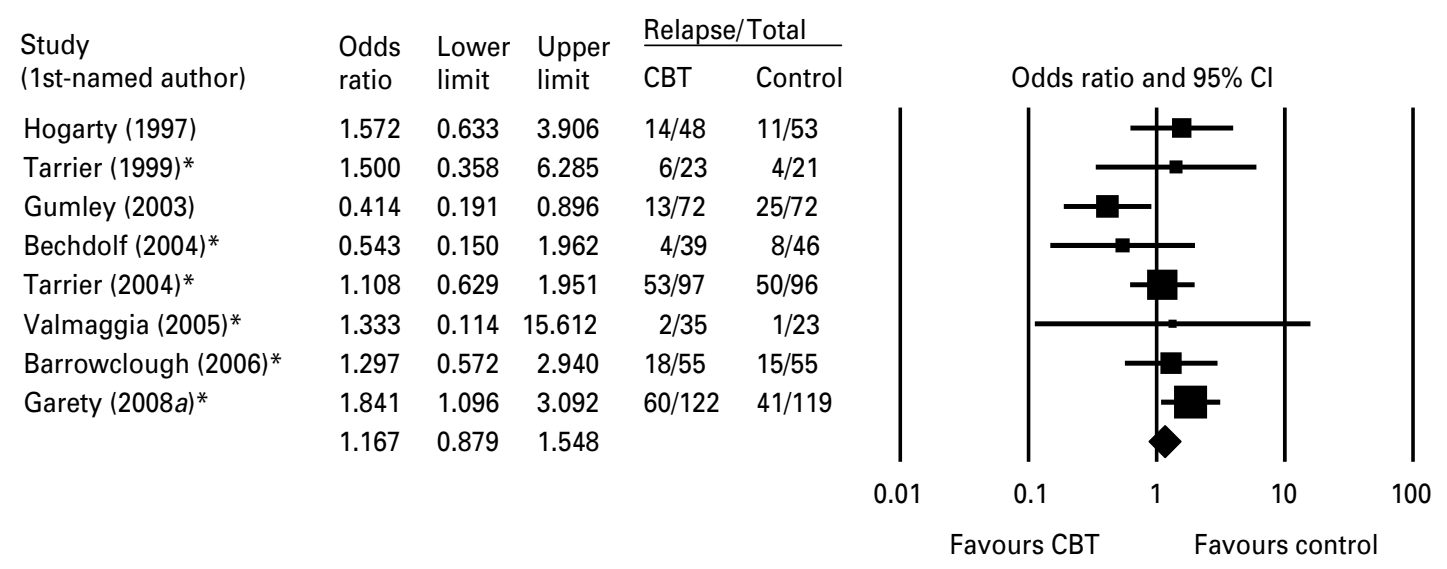

Fig. 2. Studies of the effectiveness of cognitive behavioural therapy (CBT) in reducing relapse in schizophrenia (* indicates blind study).

effect size for positive symptoms was $-0.19(95 \% \mathrm{CI}$ -0.37 to $-0.02, p=0.03)$, favouring CBT. Once again, however, the result was moderated by blindness: the effect size in the six blind studies was -0.08 compared to -0.87 in the two non-blind studies $[\mathrm{QB}(1)=9.28$, $p=0.002]$. The pooled effect size for negative symptoms was $-0.02(95 \% \mathrm{CI}-0.22$ to +0.18$)$; here, blindness did not moderate the effect size [effect size for five blind studies $+0.04 v$. -0.26 for two non-blind studies, $\mathrm{QB}(1)=1.36, p=0.24]$.

\section{Effectiveness against relapse}

Eight studies were found. These had follow-up periods of 6 months to 3 years. We did not include two studies (Drury et al. 2000; Turkington et al. 2008) because there was a 5-year interval between treatment and assessment during which there was no intervention or evaluation. Three of the studies compared CBT against TAU, and five included comparison groups of supportive counselling. Six rated relapse under blind conditions and two under non-blind conditions. The studies defined relapse in terms of increases in positive symptoms, usually requiring that the increase lasted a specified period and sometimes with a requirement of hospitalization or change in management (see Appendix).

The findings are shown in Fig. 2. The pooled OR for these studies was 1.17 (95\% CI 0.88-1.55, $p=0.29$ ), non-significantly favouring TAU. The studies were not significantly heterogeneous $[Q(7)=11.89, p=0.10]$. Blindness moderated the effect size at trend level [OR for six blind studies 1.35 v. 0.72 for two non-blind studies, $\mathrm{QB}(1)=3.28, p=0.07]$. However, use of control intervention was not a significant moderating factor $[\mathrm{QB}(1)=0.02, p=0.89]$. Once again, there was nothing to suggest that inclusion of studies using group CBT was influencing the result [OR for six studies using individual CBT 1.12 v. 1.01 for two studies using group $\mathrm{CBT}, \mathrm{QB}(1)=0.20, p=0.66]$.

In the study of Garety et al. (2008a) we analysed relapse data in patients who had made a full or partial recovery. However, Garety et al. (2008b) have argued that these rates do not reflect the true intention-to-treat effect because patients were randomized to CBT or TAU while they were ill; some failed to recover (CBT, $n=9$; TAU, $n=18$ ) and so did not have the opportunity to relapse. Adjusting the total numbers for CBT and TAU to include patients who were randomized but did not recover made little difference to the pooled OR $(1.20,95 \%$ CI $0.91-1.59, p=0.19)$.

\section{Major depression \\ Effectiveness against symptoms}

Ten studies were found. These all excluded patients with bipolar disorder or psychotic depression. Six of the studies compared patients against a control psychological intervention and four against pill placebo. The studies all measured symptoms using the observer-rated Hamilton Depression Rating Scale (HAMD) or the self-rated Beck Depression Inventory (BDI), or both. Because the former scale is observer rated and the latter a self-rating questionnaire, we meta-analysed data from these scales separately.

Figure 3 shows the result for the nine studies using the HAMD. The pooled effect size was $-0.28(95 \%$ CI -0.45 to $-0.12, p=0.001$ ), significantly favouring CBT. The studies were not heterogeneous $[Q(8)=9.40$, $p=0.31]$. The effect size was significantly greater in the four studies comparing CBT to pill placebo than in the five comparing it to control psychological intervention $[-0.41$ v. $0.00, \mathrm{QB}(1)=4.94, p=0.03]$. Blindness of evaluations did not significantly moderate the 


\begin{tabular}{llrll} 
& & \multicolumn{3}{c}{ Statistics for each study } \\
\cline { 3 - 5 } Group by & Study & Hedges' & Lower & Upper \\
control type & (1st-named author) & $g$ & limit & limit \\
Control psych & Miller (1989) & -0.417 & -1.145 & 0.310 \\
Control psych & Bowers (1990)* & -0.116 & -0.956 & 0.725 \\
Control psych & Beutler (1991) & 0.159 & -0.443 & 0.760 \\
Control psych & Scott (1992) & 0.306 & -0.205 & 0.817 \\
Control psych & Murphy (1995) & -0.428 & -1.213 & 0.356 \\
Control psych & & -0.003 & -0.298 & 0.291 \\
Pill placebo & Elkin (1989)* & -0.317 & -0.673 & 0.040 \\
Pill placebo & Jarrett (1999)* & -0.529 & -0.994 & -0.064 \\
Pill placebo & DeRubeis (2005)* & -0.437 & -0.797 & -0.077 \\
Pill placebo & Dimidjian (2006)* & -0.400 & -0.842 & 0.041 \\
Pill placebo & & -0.409 & -0.608 & -0.210 \\
Overall & & -0.282 & -0.447 & -0.117
\end{tabular}

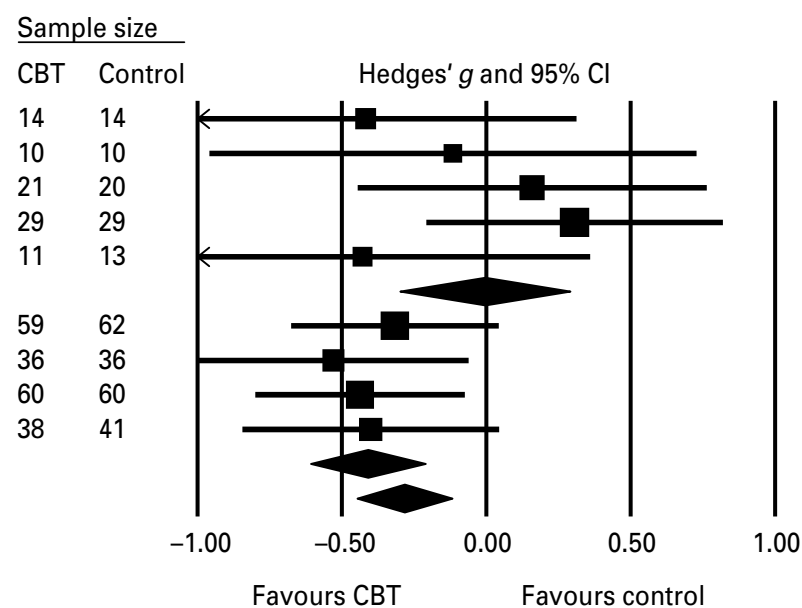

Fig. 3. Studies of the effectiveness of cognitive behavioural therapy (CBT) against symptoms in major depression ( ${ }^{*}$ indicates blind study).

effect size in these studies [pooled effect size for five blind studies $-0.39 v$ v -0.16 in three non-blind studies; $\mathrm{QB}(1)=1.00, p=0.32$ ] (the study of Scott and Freeman, 1992 was excluded from this analysis because of uncertainty over whether blindness had been maintained).

The pooled effect size for the eight studies using the BDI was similar at -0.27 (95\% CI -0.45 to -0.08 , $p=0.004)$. Use of psychological control intervention (five studies) or pill placebo (three studies) did not moderate the effect size in these studies $(-0.27 v$. $-0.27)$. The BDI is a self-rated scale and so none of these studies could be considered blind.

\section{Effectiveness against relapse}

Nine studies were included. We excluded four studies (Evans et al. 1992; Hollon et al. 2005; Segal et al. 2006; Dobson et al. 2008) because of systematic bias: the patients in the control group, but not those in the CBT group, had been treated with antidepressant medication until immediately before withdrawal at the start of the study, so potentially increasing the risk of depressive relapse in this group. All but one of the studies compared CBT to TAU (Perlis et al. 2002 compared it to pill placebo), and in all but one cases relapse was determined by an assessor who was blind to allocation. Relapse was typically defined as development of symptoms meeting diagnostic criteria for major depression; however, three studies allowed a supplementary criterion based on development of depressive symptoms exceeding a predetermined threshold but not meeting criteria for major depression (Shea et al. 1992; Paykel et al. 1999; Perlis et al. 2002).

The studies are summarized in Fig. 4. The pooled OR was 0.53 (95\% CI $0.40-0.71, p<0.001)$. The studies were not significantly heterogeneous $[Q(7)=8.60, p=$ 0.38]. All, or nearly all, of the studies were blind (blindness was not commented on in the study of Shea et al. 1992), and all but one (Perlis et al. 2002) compared CBT to TAU. Therefore, these moderating variables were not examined.

In two studies patients in both groups remained on antidepressant medication throughout the follow-up period, whereas in five, both groups were withdrawn from medication either before study entry or within the first 20 weeks of a 2-year follow-up (in the other two studies some patients in both groups were treated). The pooled ORs for studies on treated and untreated patients were 0.52 and 0.45 respectively $[\mathrm{QB}(1)=0.17, p=0.67]$.

\section{Bipolar disorder}

\section{Effectiveness against relapse}

There were no includable trials of CBT as a treatment for acutely ill patients. Four controlled trials of CBT for prevention of relapse have been carried out and are shown in Fig. 5. They all compared CBT to TAU and the assessments were all made under blind conditions. In three of the studies relapse was defined as development of symptoms sufficient to meet diagnostic criteria for major depression, mania, hypomania, or a mixed state; the fourth required a defined period of moderate/severe or incapacitating depressive or manic symptoms. The pooled OR for the four studies was insignificant at 0.78 (95\% CI 0.53-1.15, $p=0.22)$.

\section{Discussion}

Studies of psychological therapies in major psychiatric disorder have not used, and perhaps will never be able 


\begin{tabular}{llllllc} 
Study & Odds & & Lower & Upper & & \multicolumn{2}{c}{ Relapse/Total } \\
\cline { 6 - 7 } (1st-named author) & $\begin{array}{l}\text { ratio } \\
\text { limit }\end{array}$ & limit & CBT & Control \\
Shea (1992) & 1.071 & 0.288 & 3.985 & $9 / 23$ & $6 / 16$ \\
Fava (1994)* & 0.357 & 0.078 & 1.627 & $3 / 21$ & $7 / 22$ \\
Fava (1998)* & 0.104 & 0.027 & 0.408 & $5 / 23$ & $16 / 22$ \\
Paykel (1999)* & 0.473 & 0.244 & 0.916 & $23 / 80$ & $35 / 76$ \\
Teasdale (2000)* & 0.571 & 0.290 & 1.124 & $31 / 71$ & $38 / 66$ \\
Jarrett (2001)* & 0.655 & 0.271 & 1.583 & $14 / 41$ & $19 / 43$ \\
Perlis (2002)* & 0.787 & 0.202 & 3.071 & $4 / 66$ & $5 / 66$ \\
Ma (2004)* & 0.387 & 0.151 & 0.995 & $14 / 36$ & $23 / 37$ \\
Bockting (2005)* & 0.682 & 0.370 & 1.259 & $49 / 88$ & $54 / 84$ \\
& 0.533 & 0.398 & 0.715 & &
\end{tabular}

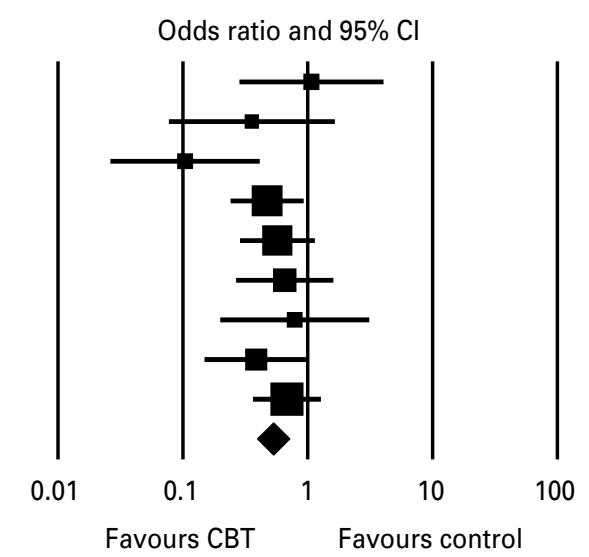

Fig. 4. Studies of the effectiveness of cognitive behavioural therapy (CBT) in reducing relapse in major depression (* indicates blind study).

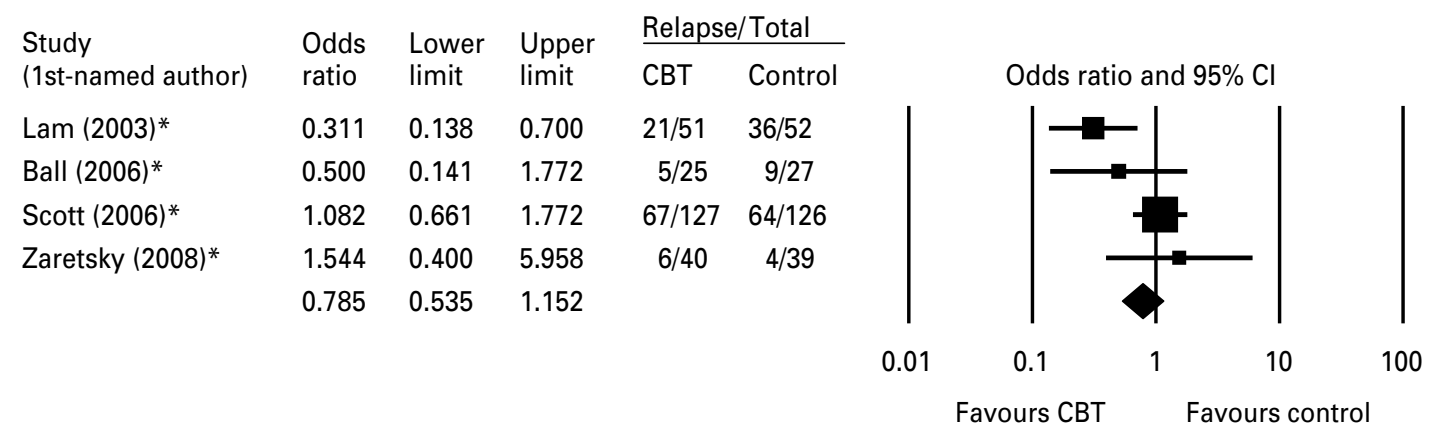

Fig. 5. Studies of the effectiveness of cognitive behavioural therapy (CBT) in reducing relapse in bipolar disorder (* indicates blind study).

to use, precisely the same methodology as that used to establish the efficacy of drug treatments, namely the double-blind, placebo-controlled trial. However, when those studies whose design approximates to this methodology are reviewed, their findings are at variance with the conclusions expressed in review articles, meta-analyses, editorials and even government documents.

The contrast is at its starkest in schizophrenia. In a recent editorial, Kingdon (2006) stated: 'More than 20 randomized controlled trials and five meta-analyses have shown cognitive behaviour therapy to be beneficial in schizophrenia, reducing both positive and negative symptoms during therapy and beyond.' Yet pooling the results of nine trials comparing CBT to non-specific control interventions reveals no indication of effectiveness. Nor does meta-analysis of a similar-sized body of evidence of CBT for relapse prevention yield any evidence of an effect. CBT for schizophrenia thus finds itself in the unusual position of being recommended in the revised NICE guideline (NICE, 2009), despite having failed in all of the treatment studies that used both control interventions and blind evaluations, and after the authors of the largest trial of relapse prevention (Garety et al. 2008a) concluded that 'generic CBT for psychosis is not indicated for routine relapse prevention in people recovering from a recent relapse of schizophrenia.'

It could be objected that our meta-analysis of positive symptom scores revealed a small but significant effect size [ $-0.19(95 \% \mathrm{CI}-0.37$ to -0.02$), p=0.03]$ in favour of CBT. However, this advantage seemed clearly to reflect the lack of blindness of two of the trials; CBT showed no evidence of effectiveness against positive symptoms in the pooled results from six trials that used both control interventions and blind evaluations. Another ground for appeal might be that one relatively large study of the effectiveness of CBT in schizophrenia (Sensky et al. 2000) found 
that, although CBT was no better than a control intervention of befriending at the end of the 9-month treatment period, it did show a significant advantage at follow-up a further 9 months later. However, delayed or enduring effects have not been observed in other studies (Tarrier et al. 1999, 2004), and the most recent meta-analysis (NICE, 2008) found effect sizes for CBT against 'active controls' (mainly non-specific control interventions, but in one case cognitive remediation therapy) of only $-0.18(95 \%$ CI -0.39 to +0.03 , five studies) at 12 -month follow-up and -0.08 (95\% CI -0.40 to +0.24 , three studies) at 24 months.

A final objection could be that, in the meta-analysis of relapse rates, we did not include studies that used hospitalization as an index of relapse. This decision excluded a large study which found that CBT significantly reduced the rate of subsequent hospitalization in schizophrenia (Turkington et al. 2006). The NICE (2009) meta-analysis of this and four other studies also found a significant advantage for CBT in reducing rehospitalization (relative risk $0.76,95 \%$ CI $0.61-0.94$ ). Nevertheless, hospitalization is not the same thing as relapse; the decision to admit a schizophrenic patient depends not only on their clinical status but also on considerations of whether there is support outside hospital, whether the patient is likely to comply with treatment at home, etc., judgements of which could be influenced by knowledge that he or she is in the active treatment arm of a trial. Indeed, the fact that Turkington et al.'s (2006) trial, where hospitalization was the outcome measure, and Garety et al.'s (2008a) similarly large trial, where relapse was the outcome measure, had such completely contradictory results attests to the reality of the difference between these two measures.

However, CBT does emerge from our metaanalytical review as an effective treatment for major depression, both as a treatment for acute symptoms and for relapse prevention. Nevertheless, there is a qualification to this conclusion: at 0.28 (HAMD) and 0.27 (BDI) the pooled effect size for the acute treatment studies was in the small range, implying only modest therapeutic benefit. These findings bear comparison with those of the most exhaustive meta-analysis of psychological treatments for depression to date, the National Health Service (NHS) R\&D Health Technology Assessment systematic review of brief psychological treatments for depression (Churchill et al. 2001). This found that all of a range of psychotherapeutic interventions showed significant advantages when compared to TAU or a waiting list control. CBT was also found to be significantly superior to supportive therapy. However, here the authors went on to state: 'The overall quality score of the trials appeared to have a considerable effect on recovery and mean differences, with lower-scoring trials demonstrating a pronounced and highly significant difference and higher-scoring trials demonstrating no significant differences.' Perhaps, more than anything else, our review makes it clear that a large, methodologically rigorous trial comparing CBT to a nonspecific control intervention in depression, similar to the several that exist in schizophrenia, has yet to be carried out. We were able to find only five such studies, all of which were small and only one of which was carried out under blind conditions. This might be considered a somewhat slender evidence base on which to introduce 250 treatment centres providing CBT for depression and anxiety across the UK.

For understandable reasons, little work has examined the usefulness of CBT in patients who are acutely manic or hypomanic. However, pilot studies (Lam et al. 2000; Scott et al. 2001) gave grounds for optimism for its use in relapse prevention. Three out of the four formal trials then went on to find no significant advantage for CBT, including one with very large numbers $(n=253)$. Meta-analysis of these trials supports the conclusion that this form of psychological therapy is ineffective in preventing relapse in bipolar disorder.

A certain amount of ambiguity concerning the nature of control interventions is evident in the metaanalytical literature on CBT. Sometimes the term 'active control' is used (e.g. NICE, 2009), with the implication, not always correct, that, similar to how the term is used in drug studies, the therapy is being compared against an intervention that also has established therapeutic benefits. In other meta-analyses, a strategy is adopted of evaluating CBT systematically against a range of different therapies, some of which, such as relaxation and supportive counselling, would be expected to have little or no therapeutic effect, whereas others, such as psychodynamic therapy, have clear therapeutic aims (e.g. Churchill et al. 2001; Cuijpers et al. 2008). However, it is important not to lose sight of the fact that we only included studies using control interventions that lacked any specific therapeutic effect. Thus, for example, Sensky et al. (2000) described befriending as a non-specific control intervention, whose benefits for people with schizophrenia do not have any underlying theoretical or empirical basis, where the sessions focused on neutral topics, such as hobbies, sports and current affairs, and in which psychotic or affective symptoms were not directly tackled in any way. Similarly, Churchill et al. (2001), in the NHS R\&D Health Technology Assessment systematic review of brief psychological treatments for depression, defined supportive therapy as ' an inclusive term, often used in treatment outcome 
trials to describe an attention-placebo condition to provide a comparison to active manualized psychological interventions.' Certainly, these interventions can result in symptomatic improvement, but there is no mystery as to why this should occur. Psychological interventions are susceptible to the so-called Hawthorne effect (e.g. Gillespie, 1991), the tendency of people singled out for a study of any kind to improve their performance or behaviour simply because of the special attention they receive. (The name derives from an electricity plant in the USA where a famous series of studies established that just about any intervention significantly increased the workers' productivity.)

Should evidence from well-controlled studies outweigh evidence from poorly controlled ones? Until recently the answer to this question would have been emphatically yes; it is a familiar story in medicine for a treatment to show promise in one or more open studies, and then perhaps be successful in a crossover trial, only to go on to fail miserably in double-blind, placebo-controlled, parallel group trials. This simple algorithm has been complicated by meta-analysis, which typically includes all studies, good and poor, published and unpublished, in an effort to arrive at the best possible estimate of the size of the treatment effect. Use of such a broad-brush approach makes subsequent examination of study qualities desirable, even mandatory. Yet there seems to have been a reluctance to do this in the meta-analytical literature on CBT in major psychiatric illness. Even the otherwise exemplary Cochrane meta-analysis of schizophrenia (Jones et al. 2004), which carried out separate analyses of CBT against TAU and supportive counselling, still failed to examine the moderating effect of blindness. The authors of meta-analyses of CBT for depression seem unperturbed by the fact that they are basing their conclusions on studies that have often been carried out against TAU or a waiting list control; that have not always been randomized; that sometimes failed to use diagnostic criteria; and that so far have ignored the moderating effect of blindness altogether. These issues are not trivial; the findings of our meta-analysis could be viewed as an object lesson on the importance of taking such sources of bias into account.

\section{Acknowledgements}

This work was supported by the Instituto de Salud Carlos III, Centro de Investigación en Red de Salud Mental, CIBERSAM.

\section{Declaration of Interest}

None.

\section{Note}

Supplementary material accompanies this paper on the Journal's website (http:/ /journals.cambridge.org/ psm).

\section{References}

Ball JR, Mitchell PB, Corry JC, Skillecorn A, Smith M, Malhi GS (2006). A randomized controlled trial of cognitive therapy for bipolar disorder: focus on long-term change. Journal of Clinical Psychiatry 67, 277-286.

Basco MR, Rush AJ (2007). Cognitive Therapy for Bipolar Disorder, 2nd edn. Guilford Press: New York.

Barrowclough C, Haddock G, Lobban F, Jones S, Siddle R, Roberts C, Gregg L (2006). Group cognitive-behavioural therapy for schizophrenia. Randomised controlled trial. British Journal of Psychiatry 189, 527-532.

Bechdolf A, Knost B, Kuntermann C, Schiller S, Klosterkotter J, Hambrecht M, Pukrop R (2004). A randomized comparison of group cognitive-behavioural therapy and group psychoeducation in patients with schizophrenia. Acta Psychiatrica Scandinavica 110, 21-28.

Beutler LE, Engle D, Mohr D, Daldrup RJ, Bergan J, Meredith K, Merry W (1991). Predictors of differential response to cognitive, experiential, and self-directed psychotherapeutic procedures. Journal of Consulting and Clinical Psychology 59, 333-340.

Bockting CL, Schene AH, Spinhoven P, Koeter MW, Wouters LF, Huyser J, Kamphuis JH (2005). Preventing relapse/recurrence in recurrent depression with cognitive therapy: a randomized controlled trial. Journal of Consulting and Clinical Psychology 73, 647-657.

Bowers WA (1990). Treatment of depressed in-patients. Cognitive therapy plus medication, relaxation plus medication, and medication alone. British Journal of Psychiatry 156, 73-78.

Churchill R, Hunot V, Corney R, Knapp M, McGuire H, Tylee A, Wessely S (2001). A systematic review of controlled trials of the effectiveness and cost-effectiveness of brief psychological treatments for depression. Health Technology Assessment 5, 1-173.

Cuijpers P, van Straten A, Andersson G, van Oppen P (2008). Psychotherapy for depression in adults: a meta-analysis of comparative outcome studies. Journal of Consulting and Clinical Psychology 76, 909-922.

DeRubeis RJ, Hollon SD, Amsterdam JD, Shelton RC, Young PR, Salomon RM, O'Reardon JP, Lovett ML, Gladis MM, Brown LL, Gallop R (2005). Cognitive therapy vs. medications in the treatment of moderate to severe depression. Archives of General Psychiatry 62, 409-416.

Dimidjian S, Hollon SD, Dobson KS, Schmaling KB, Kohlenberg RJ, Addis ME, Gallop R, McGlinchey JB, Markley DK, Gollan JK, Atkins DC, Dunner DL, Jacobson NS (2006). Randomized trial of behavioral activation, cognitive therapy, and antidepressant medication in the acute treatment of adults with major depression. Journal of Consulting and Clinical Psychology 74, 658-670. 
Dobson KS, Hollon SD, Dimidjian S, Schmaling KB, Kohlenberg RJ, Gallop RJ, Rizvi SL, Gollan JK, Dunner DL, Jacobson NS (2008). Randomized trial of behavioral activation, cognitive therapy, and antidepressant medication in the prevention of relapse and recurrence in major depression. Journal of Consulting and Clinical Psychology 76, 468-477.

Drury V, Birchwood M, Cochrane R (2000). Cognitive therapy and recovery from acute psychosis: a controlled trial. 3. Five-year follow-up. British Journal of Psychiatry 177, 8-14.

Drury V, Birchwood M, Cochrane R, Macmillan F (1996). Cognitive therapy and recovery from acute psychosis: a controlled trial. I. Impact on psychotic symptoms. British Journal of Psychiatry 169, 593-601.

Durham RC, Guthrie M, Morton RV, Reid DA, Treliving LR, Fowler D, Macdonald RR (2003). Tayside-Fife clinical trial of cognitive-behavioural therapy for medication-resistant psychotic symptoms. Results to 3-month follow-up. British Journal of Psychiatry 182, 303-311.

Elkin I, Shea MT, Watkins JT, Imber SD, Sotsky SM, Collins JF, Glass DR, Pilkonis PA, Leber WR, Docherty JP, Fiester SJ, Parloff MB (1989). National Institute of Mental Health treatment of depression collaborative research program. General effectiveness of treatments. Archives of General Psychiatry 46, 971-982.

Evans MD, Hollon SD, DeRubeis RJ, Piasecki JM, Grove WM, Garvey MJ, Tuason VB (1992). Differential relapse following cognitive therapy and pharmacotherapy for depression. Archives of General Psychiatry 49, 802-808.

Fava GA, Grandi S, Zielezny M, Canestrari R, Morphy MA (1994). Cognitive behavioral treatment of residual symptoms in primary major depressive disorder. American Journal of Psychiatry 151, 1295-1299.

Fava GA, Rafanelli C, Grandi S, Conti S, Belluardo P (1998). Prevention of recurrent depression with cognitive behavioral therapy: preliminary findings. Archives of General Psychiatry 55, 816-820.

Garety PA, Fowler DG, Freeman D, Bebbington P, Dunn G, Kuipers E (2008a). Cognitive-behavioural therapy and family intervention for relapse prevention and symptom reduction in psychosis: randomised controlled trial. British Journal of Psychiatry 192, 412-423.

Garety PA, Fowler DG, Freeman D, Bebbington P, Dunn G, Kuipers E (2008b). Risk of harm after psychological intervention: authors' reply. British Journal of Psychiatry 193, 345-346.

Gillespie R (1991). Manufacturing Knowledge: A History of the Hawthorne Experiments. Cambridge University Press: Cambridge.

Gloaguen V, Cottraux J, Cucherat M, Blackburn IM (1998). A meta-analysis of the effects of cognitive therapy in depressed patients. Journal of Affective Disorders 49, 59-72.

Gould RA, Mueser KT, Bolton E, Mays V, Goff D (2001). Cognitive therapy for psychosis in schizophrenia: an effect size analysis. Schizophrenia Research 48, 335-342.

Gumley A, O'Grady M, McNay L, Reilly J, Power K, Norrie J (2003). Early intervention for relapse in schizophrenia: results of a 12-month randomized controlled trial of cognitive behavioural therapy. Psychological Medicine 33, 419-431.

Haddock G, Barrowclough C, Shaw JJ, Dunn G, Novaco RW, Tarrier N (2009). Cognitive-behavioural therapy $v$. social activity therapy for people with psychosis and a history of violence: randomised controlled trial. British Journal of Psychiatry 194, 152-157.

Hogarty GE, Kornblith SJ, Greenwald D, DiBarry AL, Cooley S, Ulrich RF, Carter M, Flesher S (1997).

Three-year trials of personal therapy among schizophrenic patients living with or independent of family. I: Description of study and effects on relapse rates. American Journal of Psychiatry 154, 1504-1513.

Hollon SD, DeRubeis RJ, Shelton RC, Amsterdam JD, Salomon RM, O'Reardon JP, Lovett ML, Young PR, Haman KL, Freeman BB, Gallop R (2005). Prevention of relapse following cognitive therapy vs medications in moderate to severe depression. Archives of General Psychiatry 62, 417-422.

Jackson HJ, McGorry PD, Killackey E, Bendall S, Allott K, Dudgeon P, Gleeson J, Johnson T, Harrigan S (2008). Acute-phase and 1-year follow-up results of a randomized controlled trial of CBT versus befriending for first-episode psychosis: the ACE project. Psychological Medicine 38, 725-735.

Jarrett RB, Kraft D, Doyle J, Foster BM, Eaves GG, Silver PC (2001). Preventing recurrent depression using cognitive therapy with and without a continuation phase: a randomized clinical trial. Archives of General Psychiatry 58, 381-388.

Jarrett RB, Schaffer M, McIntire D, Witt-Browder A, Kraft D, Risser RC (1999). Treatment of atypical depression with cognitive therapy or phenelzine: a double-blind, placebo-controlled trial. Archives of General Psychiatry 56, 431-437.

Jones C, Cormac I, Silveira da Mota Neto JI, Campbell C (2004). Cognitive behaviour therapy for schizophrenia. Cochrane Database of Systematic Reviews 4, CD000524.

Jüni P, Douglas G Altman DG, Egger M (2001). Systematic reviews in health care: assessing the quality of controlled clinical trials. British Medical Journal 323, 42-46.

Kingdon D (2006). Psychological and social interventions for schizophrenia. British Medical Journal 333, 212-213.

Lam D, Bright J, Jones S, Hayward P, Schuck N, Chisholm D, Sham P (2000). Cognitive therapy for bipolar illness: a pilot study of relapse prevention. Cognitive Therapy Research 24, 503-520.

Lam DH, Watkins ER, Hayward P, Bright J, Wright K, Kerr N, Parr-Davis G, Sham P (2003). A randomized controlled study of cognitive therapy for relapse prevention for bipolar affective disorder: outcome of the first year. Archives of General Psychiatry 60, 145-152.

Layard R (2006). The case for psychological treatment centres. British Medical Journal 332, 1030-1032.

Lecomte $T$, Leclerc $C$, Corbière $M$, Wykes $T$, Wallace $C J$, Spidel A (2008). Group cognitive behavior therapy or social skills training for individuals with a recent onset of psychosis? Resutls of a randomized controlled trial. Journal of Nervous and Mental Disease 196, 866-875. 
Lewis S, Tarrier N, Haddock G, Bentall R, Kinderman P, Kingdon D, Siddle R, Drake R, Everitt J, Leadley $K$, Benn A, Grazebrook K, Haley C, Akhtar S, Davies L, Palmer S, Faragher B, Dunn G (2002). Randomised controlled trial of cognitive-behavioural therapy in early schizophrenia: acute-phase outcomes. British Journal of Psychiatry. Supplement 43, s91-s97.

Ma SH, Teasdale JD (2004). Mindfulness-based cognitive therapy for depression: replication and exploration of differential relapse prevention effects. Journal of Consulting and Clinical Psychology 72, 31-40.

McLean PD, Hakstian AR (1979). Clinical depression: comparative efficacy of outpatient treatments. Journal of Consulting and Clinical Psychology 47, 818-836.

Miller IW, Norman WH, Keitner GI, Dow MG (1989). Cognitive-behavioral treatment of depressed inpatients. Behavior Therapy 20, 25-47.

Murphy GE, Carney RM, Knesevich MA, Wetzel RD, Whitworth P (1995). Cognitive behavior therapy, relaxation training, and tricyclic antidepressant medication in the treatment of depression. Psychological Reports 77, 403-420.

NICE (2003). Schizophrenia: Full National Clinical Guideline on Core Interventions in Primary and Secondary Care. Gaskell and the British Psychological Society: London.

NICE (2004). Depression: Management of Depression in Primary and Secondary Care. National Institute for Clinical Excellence (NICE) Clinical Guideline, CG23. Gaskell and the British Psychological Society: London.

NICE (2009). Schizophrenia: Core Interventions in the Treatment and Management of Schizophrenia in Primary and Secondary Care (update). National Institute for Clinical Excellence: London.

Parker G, Roy K, Eyers K (2003). Cognitive behavior therapy for depression? Choose horses for courses. American Journal of Psychiatry 160, 825-834.

Paykel ES, Scott J, Teasdale JD, Johnson AL, Garland A, Moore R, Jenaway A, Cornwall PL, Hayhurst H, Abbott R, Pope M (1999). Prevention of relapse in residual depression by cognitive therapy: a controlled trial. Archives of General Psychiatry 56, 829-835.

Perlis RH, Nierenberg AA, Alpert JE, Pava J, Matthews JD, Buchin J, Sickinger AH, Fava M (2002). Effects of adding cognitive therapy to fluoxetine dose increase on risk of relapse and residual depressive symptoms in continuation treatment of major depressive disorder. Journal of Clinical Psychopharmacology 22, 474-480.

Picchioni MM, Murray RM (2007). Schizophrenia. British Medical Journal 335, 91-95.

Pilling S, Bebbington P, Kuipers E, Garety P, Geddes J, Orbach G, Morgan C (2002). Psychological treatments in schizophrenia: I. Meta-analysis of family intervention and cognitive behaviour therapy. Psychological Medicine 32, 763-782.

Pinto J, La Pia S, Mennella R, Giorgio D, DeSimone L (1999). Cognitive-behavioral therapy and clozapine for clients with treatment-refractory schizophrenia. Psychiatric Services 50, 901-904.
Rector NA, Beck AT (2001). Cognitive behavioral therapy for schizophrenia: an empirical review. Journal of Nervous and Mental Diseases 189, 278-287.

Scott AI, Freeman CP (1992). Edinburgh primary care depression study: treatment outcome, patient satisfaction, and cost after 16 weeks. British Medical Journal 304, 883-887.

Scott J, Colom F, Vieta E (2007). A meta-analysis of relapse rates with adjunctive psychological therapies compared to usual psychiatric treatment for bipolar disorders. International Journal of Neuropsychopharmacology 10, 123-129.

Scott J, Colom F (2005). Psychosocial treatments for bipolar disorders. Psychiatric Clinics of North America 28, 371-384.

Scott J, Garland A, Moorhead S (2001). A pilot study of cognitive therapy in bipolar disorders. Psychological Medicine 31, 459-467.

Scott J, Paykel E, Morriss R, Bentall R, Kinderman P, Johnson T, Abbott R, Hayhurst H (2006). Cognitivebehavioural therapy for severe and recurrent bipolar disorders: randomised controlled trial. British Journal of Psychiatry 188, 313-320.

Segal ZV, Kennedy S, Gemar M, Hood K, Pedersen R, Buis $T$ (2006). Cognitive reactivity to sad mood provocation and the prediction of depressive relapse. Archives of General Psychiatry 63, 749-755.

Sensky T, Turkington D, Kingdon D, Scott JL, Scott J, Siddle R, O'Carroll M, Barnes, T (2000). A randomized controlled trial of cognitive-behavioral therapy for persistent symptoms in schizophrenia resistant to medication. Archives of General Psychiatry 57, 165-172.

Shea MT, Elkin I, Imber SD, Sotsky SM, Watkins JT, Collins JF, Pilkonis PA, Beckham E, Glass DR, Dolan RT, Parloff MB (1992). Course of depressive symptoms over follow-up. Findings from the National Institute of Mental Health Treatment of Depression Collaborative Research Program. Archives of General Psychiatry 49, 782-787.

Tarrier N, Lewis S, Haddock G, Bentall R, Drake R, Kinderman P, Kingdon D, Siddle R, Everitt J, Leadley K, Benn A, Grazebrook K, Haley C, Akhtar S, Davies L, Palmer S, Dunn G (2004). Cognitive-behavioural therapy in first-episode and early schizophrenia: 18-month follow-up of a randomised controlled trial. British Journal of Psychiatry 184, 231-239.

Tarrier N, Wittkowski A, Kinney C, McCarthy E, Morris J, Humphreys L (1999). Durability of the effects of cognitive-behavioural therapy in the treatment of chronic schizophrenia: 12-month follow-up. British Journal of Psychiatry 174, 500-504.

Tarrier N, Wykes T (2004). Is there evidence that cognitive behaviour therapy is an effective treatment for schizophrenia? A cautious or cautionary tale? Behaviour Research and Therapy 42, 1377-1401.

Teasdale JD, Segal ZV, Williams JM, Ridgeway VA, Soulsby JM, Lau MA (2000). Prevention of relapse/ recurrence in major depression by mindfulness-based cognitive therapy. Journal of Consulting and Clinical Psychology 68, 615-623.

Turkington D, Kingdon D, Rathod S, Hammond K, Pelton J, Mehta R (2006). Outcomes of an effectiveness 
trial of cognitive-behavioural intervention by mental health nurses in schizophrenia. British Journal of Psychiatry 189, 36-40.

Turkington D, Sensky T, Scott J, Barnes TR, Nur U, Siddle R, Hammond K, Samarasekara N, Kingdon D (2008). A randomized controlled trial of cognitivebehavior therapy for persistent symptoms in schizophrenia: a five-year follow-up. Schizophrenia Research 98, 1-7.

Valmaggia LR, van der Gaag M, Tarrier N, Pijnenborg M, Slooff CJ (2005). Cognitive-behavioural therapy for refractory psychotic symptoms of schizophrenia resistant to atypical antipsychotic medication. Randomised controlled trial. British Journal of Psychiatry 186, 324-330.

Vittengl JR, Clark LA, Dunn TW, Jarrett RB (2007). Reducing relapse and recurrence in unipolar depression: a comparative metaanalysis of cognitive-behavioral therapy's effects. Journal of Consulting and Clinical Psychology 75, 475-488.

Wykes T, Steel C, Everitt B, Tarrier N (2008). Cognitive behavior therapy for schizophrenia: effect sizes, clinical models, and methodological rigor. Schizophrenia Bulletin 34, 523-537.

Zaretsky A, Lancee W, Miller C, Harris A, Parikh SV (2008). Is cognitive-behavioural therapy more effective than psychoeducation in bipolar disorder? Canadian Journal of Psychiatry 53, 441-448.

Zimmermann G, Favrod J, Trieu VH, Pomini V (2005). The effect of cognitive behavioral treatment on the positive symptoms of schizophrenia spectrum disorders: a meta-analysis. Schizophrenia Research 77, 1-9. 
Table A1. Treatment studies

\begin{tabular}{|c|c|c|c|c|c|c|}
\hline Study & Sample sizes & Blindness & $\begin{array}{l}\text { Diagnostic } \\
\text { criteria }\end{array}$ & $\begin{array}{l}\text { Duration of } \\
\text { therapy }\end{array}$ & Patient type & Effect size (Hedges corrected) \\
\hline \multicolumn{7}{|l|}{ I. Schizophrenia } \\
\hline Drury et al. (1996) & $\begin{array}{l}20 \text { CBT } \\
20 \text { recreational } \\
\text { therapy }\end{array}$ & Non-blind & $\mathrm{Own}^{\mathrm{a}}$ & 12 weeks & $\begin{array}{l}\text { In-patients with psychotic symptoms } \\
\text { Acute and chronic }\end{array}$ & $\begin{array}{l}-0.54 \text { (averaged) } \\
\text { (Manchester positive }-0.94 ; \text { Manchester } \\
\text { negative }-0.18 \text { ) }\end{array}$ \\
\hline Pinto et al. (1999) & $\begin{array}{l}19 \mathrm{CBT}+\mathrm{SST} \\
18 \text { supportive therapy }\end{array}$ & Non-blind & DSM-IV & 6 months & $\begin{array}{l}\text { In- and out-patients with treatment- } \\
\text { refractory psychosis } \\
\text { At least some chronic }\end{array}$ & $\begin{array}{l}-0.72(\mathrm{BPRS}) \\
(\mathrm{SAPS},-0.79, \text { SANS }-0.33)\end{array}$ \\
\hline Tarrier et al. (1999) & $\begin{array}{l}23 \text { CBT } \\
21 \text { supportive } \\
\text { counselling }\end{array}$ & Blind & DSM-III-R & 10 weeks & $\begin{array}{l}\text { Out-patients with persistent positive } \\
\text { symptoms } \\
\text { Acute and chronic }\end{array}$ & $\begin{array}{l}-0.26 \text { (averaged) } \\
\text { (BPRS positive }-0.47, \text { SANS }-0.07 \text { ) }\end{array}$ \\
\hline Sensky et al. (2000) & $\begin{array}{l}46 \text { CBT } \\
44 \text { befriending }\end{array}$ & Blind & $\begin{array}{l}\text { ICD-10/ } \\
\text { DSM-IV }\end{array}$ & 9 months & $\begin{array}{l}\text { Patients with persistent symptoms causing } \\
\text { distress/dysfunction } \\
\text { Chronic }\end{array}$ & $\begin{array}{l}-0.08(\mathrm{CPRS}) \\
(\mathrm{SANS}+0.07)\end{array}$ \\
\hline Lewis et al. (2002) & $\begin{array}{l}78 \text { CBT } \\
71 \text { supportive } \\
\text { counselling }\end{array}$ & Blind & DSM-IV & 5 weeks & $\begin{array}{l}\text { In- or day-patients with positive symptoms } \\
\text { First or second episode }\end{array}$ & $\begin{array}{l}+0.10 \text { (PANSS) } \\
\text { (PANSS positive }+0.09)\end{array}$ \\
\hline $\begin{array}{l}\text { Durham et al. } \\
\text { (2003) }\end{array}$ & $\begin{array}{l}22 \text { CBT } \\
19 \text { supportive } \\
\text { counselling }\end{array}$ & Blind & $\begin{array}{l}\text { ICD-10/ } \\
\text { DSM-IV }\end{array}$ & 9 months & $\begin{array}{l}\text { In- and out-patients with persistent positive } \\
\text { symptoms } \\
\text { Chronic }\end{array}$ & $\begin{array}{l}+0.06 \text { (PANSS) } \\
\text { (PSYRATS positive }+0.02 \text { averaged) }\end{array}$ \\
\hline $\begin{array}{l}\text { Bechdolf et al. } \\
\text { (2004) }\end{array}$ & $\begin{array}{l}39 \text { group CBT } \\
46 \text { group psycho- } \\
\text { education }\end{array}$ & Blind & ICD-10 & 8 weeks & $\begin{array}{l}\text { In-patients (acute admissions) } \\
\text { Acute and chronic }\end{array}$ & $\begin{array}{l}+0.17 \text { (averaged) } \\
\text { (PANSS positive }-0.02 \text {, PANSS negative } \\
\quad+0.16 \text {, PANSS general }+0.39 \text { ) }\end{array}$ \\
\hline $\begin{array}{l}\text { Valmaggia et al. } \\
\text { (2005) }\end{array}$ & $\begin{array}{l}35 \text { CBT } \\
23 \text { supportive } \\
\text { counselling }\end{array}$ & Blind & DSM-IV & 22 weeks & $\begin{array}{l}\text { Acute and chronic in-patients with } \\
\text { persistent positive symptoms }\end{array}$ & $\begin{array}{l}+0.06 \text { (averaged) } \\
\text { (PANSS positive }-0.30 \text {, PANSS negative } \\
+0.36 \text {, PANSS general }+0.13 \text { ) }\end{array}$ \\
\hline $\begin{array}{l}\text { Haddock et al. } \\
(2009)^{\mathrm{b}}\end{array}$ & $\begin{array}{l}28 \mathrm{CBT}^{\mathrm{c}} \\
29 \text { social activity } \\
\text { therapy }\end{array}$ & Blind & DSM-IV & 6 months & $\begin{array}{l}\text { In- and out-patients with persistent positive } \\
\text { symptoms }\end{array}$ & $\begin{array}{l}-0.23 \text { (PANSS) } \\
\text { (PANSS positive }-0.16, \text { PANSS negative } \\
-0.38 \text { ) }\end{array}$ \\
\hline \multicolumn{7}{|l|}{ II. Major depression } \\
\hline $\begin{array}{l}\text { McLean \& } \\
\text { Hakstian (1979) }\end{array}$ & $\begin{array}{l}42 \mathrm{CBT} \\
43 \text { relaxation }\end{array}$ & Non-blind & Feigner & 10 weeks & $\begin{array}{l}\text { Out-patients } \\
\text { Not on drug treatment }\end{array}$ & $\begin{array}{l}\text { BDI }-0.38 \\
\text { (calculated from proportion of } \\
\text { responders) }\end{array}$ \\
\hline
\end{tabular}




\begin{tabular}{|c|c|c|c|c|c|c|}
\hline Miller et al. (1989) & $\begin{array}{l}14 \mathrm{CBT} \\
14 \mathrm{SST}\end{array}$ & Non-blind & DSM-III & $20+$ weeks & $\begin{array}{l}\text { In-patients, continuing after discharge } \\
\text { On drug treatment }\end{array}$ & $\begin{array}{l}\text { HAMD }-0.42 \\
\text { BDI }-0.14 \\
\text { (calculated from proportion of } \\
\text { responders) }\end{array}$ \\
\hline Bowers (1990) & $\begin{array}{l}10 \mathrm{CBT} \\
10 \text { relaxation }\end{array}$ & Blind & DSM-III & 12 days & $\begin{array}{l}\text { In-patients } \\
\text { On drug treatment }\end{array}$ & $\begin{array}{l}\text { HAMD }-0.12 \\
\text { BDI }-0.07\end{array}$ \\
\hline Beutler et al. (1991) & $\begin{array}{l}21 \text { group CBT } \\
20 \text { supportive, self- } \\
\text { directed therapy }\end{array}$ & Non-blind & DSM-III & 20 weeks & $\begin{array}{l}\text { Out-patients } \\
\text { Not on drug treatment }\end{array}$ & $\begin{array}{l}\text { HAMD }+0.16 \\
\text { BDI }-0.48\end{array}$ \\
\hline $\begin{array}{l}\text { Scott \& Freeman } \\
\text { (1992) }\end{array}$ & $\begin{array}{l}29 \text { CBT } \\
29 \text { social work } \\
\text { counselling }\end{array}$ & Uncertain $^{\mathrm{d}}$ & DSM-III & 16 weeks & $\begin{array}{l}\text { Out-patients } \\
\text { Not on drug treatment }\end{array}$ & HAMD + 0.31 \\
\hline $\begin{array}{l}\text { Murphy et al. } \\
\text { (1995) }\end{array}$ & $\begin{array}{l}11 \text { CBT } \\
13 \text { relaxation }\end{array}$ & Non-blind & Feighner & 16 weeks & $\begin{array}{l}\text { Out-patients } \\
\text { Not on drug treatment }\end{array}$ & $\begin{array}{l}\text { HAMD }-0.43 \\
\text { BDI }+0.18\end{array}$ \\
\hline Elkin et al. (1989) & $\begin{array}{l}59 \text { CBT } \\
62 \text { pill placebo }\end{array}$ & Blind & RDC & 16 weeks & $\begin{array}{l}\text { Out-patients } \\
\text { Not on drug treatment }\end{array}$ & $\begin{array}{l}\text { HAMD }-0.32 \\
\text { BDI }-0.15\end{array}$ \\
\hline Jarrett et al. (1999) & $\begin{array}{l}36 \mathrm{CBT} \\
36 \text { pill placebo }\end{array}$ & Blind & DSM-III-R & 10 weeks & $\begin{array}{l}\text { Out-patients } \\
\text { Not on drug treatment }\end{array}$ & $\begin{array}{l}\text { HAMD }-0.53 \\
\text { BDI }-0.63\end{array}$ \\
\hline $\begin{array}{l}\text { DeRubeis et al. } \\
\text { (2005) }\end{array}$ & $\begin{array}{l}60 \mathrm{CBT} \\
60 \text { pill placebo }\end{array}$ & Blind & DSM-IV & 8 weeks & $\begin{array}{l}\text { Out-patients } \\
\text { Not on drug treatment }\end{array}$ & $\begin{array}{l}\text { HAMD }-0.44 \\
\text { (as given by authors) }\end{array}$ \\
\hline $\begin{array}{l}\text { Dimidjian et al. } \\
\text { (2006) }\end{array}$ & $\begin{array}{l}38 \mathrm{CBT} \\
41 \text { pill placebo }\end{array}$ & Blind & DSM-IV & 8 weeks & $\begin{array}{l}\text { Out-patients } \\
\text { Not on drug treatment }\end{array}$ & $\begin{array}{l}\text { HAMD }-0.40 \\
\text { BDI }-0.12 \\
\text { (averaged across low and } \\
\text { high severity groups) }\end{array}$ \\
\hline
\end{tabular}

CBT, Cognitive behavioural therapy; SST, social skills training; RDC, Research Diagnostic Criteria; Manchester, Manchester/Krawieka scale; BPRS, Brief Psychiatric Rating Scale; SAPS, Schedule for the Assessment of Positive Symptoms; SANS, Scale for the Assessment of Negative Symptoms; CPRS, Comprehensive Psychopathological Rating Scale;

PANSS, Positive and Negative Syndrome Scale; PSYRATS, Psychotic Symptom Rating Scales; HAMD, Hamilton Depression Rating Scale; BDI, Beck Depression Inventory.

ased World Health Organization (WHO)-based criteria for non-affective functional psychosis.

${ }^{\mathrm{b}}$ Patients also had a history of violent behaviour.

${ }^{c}$ Patient numbers at end of study approximate as exact data not given.

d Independent evaluations, but 'it is likely that the patients made them aware of their treatment'.

e Patients met DSM-III-R criteria for major depression with atypical features (maintained reactivity of mood plus two or more of hyperphagia, hypersomnia, sensation of heaviness/leaden paralysis in limbs, lifetime sensitivity to rejection). 
Table A2. Studies of relapse prevention

\begin{tabular}{|c|c|c|c|c|c|c|c|c|}
\hline Study & Sample sizes & Blindness & $\begin{array}{l}\text { Diagnostic } \\
\text { criteria }\end{array}$ & Relapse criteria & Duration of CBT & Follow-up & Patient type & Relapse rates \\
\hline \multicolumn{9}{|l|}{ I. Schizophrenia } \\
\hline Hogarty et al. (1997) & $\begin{array}{l}48 \text { CBT } \\
53 \text { supportive } \\
\text { therapy }\end{array}$ & Non-blind & RDC & $\begin{array}{l}\text { Defined increase in psychotic } \\
\text { symptoms and clinical } \\
\text { consensus }\end{array}$ & Up to 3 years & 3 years & Acute and chronic & $\begin{array}{l}14 / 48 \text { CBT } \\
11 / 53 \text { Control }\end{array}$ \\
\hline Tarrier et al. (1999) & $\begin{array}{l}23 \text { CBT } \\
21 \text { supportive } \\
\text { counselling }\end{array}$ & Blind & DSM-III-R & $\begin{array}{l}\text { Rehospitalization for clinical } \\
\text { deterioration resulting in } \\
\text { functional impairment }\end{array}$ & 3 months & 12 months & $\begin{array}{l}\text { Mainly chronic out- } \\
\text { patients with persistent } \\
\text { positive symptoms }\end{array}$ & $\begin{array}{l}\text { 6/23 CBT } \\
4 / 21 \text { Control }\end{array}$ \\
\hline Gumley et al. (2003) & $\begin{array}{l}72 \mathrm{CBT} \\
72 \mathrm{TAU}\end{array}$ & Non-blind & DSM-IV & $\begin{array}{l}\text { Hospitalization or defined } \\
\text { increase in psychotic } \\
\text { symptoms }\end{array}$ & $\begin{array}{l}12 \text { weeks } \\
+ \text { targeted } \\
\text { treatment for signs } \\
\text { of relapse }\end{array}$ & 12 months & $\begin{array}{l}\text { Relapse-prone patients, } \\
\text { at least some chronic }\end{array}$ & $\begin{array}{l}13 / 72 \mathrm{CBT} \\
25 / 72 \mathrm{TAU}\end{array}$ \\
\hline Bechdolf et al. (2004) & $\begin{array}{l}39 \text { group CBT } \\
46 \text { psycho- } \\
\text { education }\end{array}$ & Blind & ICD-10 & $\begin{array}{l}\text { Defined increase in psychotic } \\
\text { symptoms }\end{array}$ & $\begin{array}{l}8 \text { weeks } \\
+ \text { continued post- } \\
\text { discharge }\end{array}$ & 6 months & $\begin{array}{l}\text { Relapse-prone patients, } \\
\text { at least some chronic }\end{array}$ & $\begin{array}{l}\text { 4/39 CBT } \\
8 / 46 \text { Control }\end{array}$ \\
\hline Tarrier et al. (2004) & $\begin{array}{l}97 \text { CBT } \\
96 \text { supportive } \\
\text { counselling }\end{array}$ & Blind & DSM-III-R & $\begin{array}{l}\text { Exacerbation of symptoms } \\
\text { lasting }>1 \text { week and leading } \\
\text { to change in management }\end{array}$ & $\begin{array}{l}5 \text { weeks } \\
+ \text { booster sessions } \\
\text { up to } 3 \text { months }\end{array}$ & 18 months & $\begin{array}{l}\text { First- or second-episode } \\
\text { in-patients with positive } \\
\text { symptoms }\end{array}$ & $\begin{array}{l}\text { 53/97 CBT } \\
\text { 50/96 Control }\end{array}$ \\
\hline $\begin{array}{l}\text { Valmaggia et al. } \\
\text { (2005) }\end{array}$ & $\begin{array}{l}35 \text { CBT } \\
23 \text { supportive } \\
\text { counselling }\end{array}$ & Blind & DSM-IV & $\begin{array}{l}\text { Defined increase in positive } \\
\text { symptoms lasting }>3 \text { days }\end{array}$ & 22 weeks & 12 months & $\begin{array}{l}\text { Acute and chronic } \\
\text { patients with persistent } \\
\text { positive symptoms }\end{array}$ & $\begin{array}{l}2 / 35 \text { CBT } \\
1 / 23 \text { Control }\end{array}$ \\
\hline $\begin{array}{l}\text { Barrowclough et al. } \\
\text { (2006) }\end{array}$ & $\begin{array}{l}57 \text { group CBT } \\
56 \mathrm{TAU}\end{array}$ & Blind & DSM-IV & $\begin{array}{l}>2 \text {-week exacerbation of } \\
\text { symptoms requiring change } \\
\text { in management }\end{array}$ & 6 months & 12 months & $\begin{array}{l}\text { Patients with persistent } \\
\text { positive symptoms }\end{array}$ & $\begin{array}{l}18 / 55 \mathrm{CBT} \\
15 / 55 \mathrm{TAU}\end{array}$ \\
\hline Garety et al. (2008a) & $\begin{array}{l}122 \mathrm{CBT}^{\mathrm{a}} \\
119 \mathrm{TAU}^{2}\end{array}$ & Blind & DSM-IV & $\begin{array}{l}\text { Re-emergence of positive } \\
\text { symptoms lasting }>2 \text { weeks; } \\
\text { worsening of positive } \\
\text { symptoms to at least } \\
\text { moderate degree }\end{array}$ & 9 months & 24 months & $\begin{array}{l}\text { Patients with at least two } \\
\text { episodes of illness }\end{array}$ & $\begin{array}{l}60 / 122 \text { CBT } \\
41 / 119 \text { TAU }\end{array}$ \\
\hline \multicolumn{9}{|l|}{ II. Major depression } \\
\hline Shea et al. (1992) & $\begin{array}{l}23 \mathrm{CBT} \\
16 \mathrm{TAU}\end{array}$ & Not stated & RDC & $\begin{array}{l}\text { RDC major depression or } \\
\text { receiving treatment for } \\
\text { depression }\end{array}$ & 16 weeks & 18 months & $\begin{array}{l}\text { Antidepressant treatment } \\
\text { at clinician's discretion }\end{array}$ & $\begin{array}{l}9 / 23 \mathrm{CBT} \\
6 / 16 \mathrm{TAU}\end{array}$ \\
\hline Fava et al. (1994) & $\begin{array}{l}21 \mathrm{CBT} \\
22 \mathrm{TAU}\end{array}$ & Blind & RDC & RDC major depression & 20 weeks & 2 years & $\begin{array}{l}\text { Antidepressants } \\
\text { withdrawn over first } \\
20 \text { weeks }\end{array}$ & $\begin{array}{l}3 / 21 \mathrm{CBT} \\
7 / 22 \mathrm{TAU}\end{array}$ \\
\hline
\end{tabular}




\begin{tabular}{|c|c|c|c|c|c|c|c|c|}
\hline Fava et al. (1998) & $\begin{array}{l}23 \mathrm{CBT} \\
22 \mathrm{TAU}\end{array}$ & Blind & RDC & RDC major depression & 20 weeks & 2 years & $\begin{array}{l}\geqslant 3 \text { episodes with } 2 \text { in } \\
\text { past } 2.5 \text { years. } \\
\text { Antidepressants } \\
\text { withdrawn over first } \\
20 \text { weeks }\end{array}$ & $\begin{array}{l}5 / 23 \text { CBT } \\
16 / 22 \text { TAU }\end{array}$ \\
\hline Paykel et al. (1999) & $\begin{array}{l}80 \mathrm{CBT} \\
76 \mathrm{TAU}\end{array}$ & Blind & DSM-III-R & $\begin{array}{l}\text { DSM-III-R major depression or } \\
\text { increasing persistent symptoms }\end{array}$ & $\begin{array}{l}20 \text { weeks } \\
+2 \text { booster } \\
\text { sessions }\end{array}$ & 1 year & $\begin{array}{l}\text { Patients all had residual } \\
\text { symptoms. } \\
\text { Antidepressants } \\
\text { continued throughout } \\
\text { study }\end{array}$ & $\begin{array}{l}23 / 80 \mathrm{CBT} \\
35 / 76 \mathrm{TAU}\end{array}$ \\
\hline Teasdale et al. (2000) & $\begin{array}{l}71 \mathrm{CBT} \\
66 \mathrm{TAU}\end{array}$ & Blind & DSM-III-R & DSM-III-R major depression & 8 weeks & 1 year & $\begin{array}{l}\geqslant 2 \text { episodes in past } \\
5 \text { years. } \\
\text { All patients off } \\
\text { antidepressants for at } \\
\text { least } 12 \text { weeks before } \\
\text { study entry }\end{array}$ & $\begin{array}{l}31 / 71 \mathrm{CBT} \\
38 / 66 \mathrm{TAU}\end{array}$ \\
\hline Jarrett et al. (2001) & $\begin{array}{l}41 \mathrm{CBT} \\
43 \mathrm{TAU}\end{array}$ & Blind & DSM-IV & DSM-IV major depression & 8 months & 2 years & $\begin{array}{l}\geqslant 2 \text { episodes. } \\
\text { All patients drug free } \\
\text { from outset }\end{array}$ & $\begin{array}{l}14 / 41 \mathrm{CBT} \\
19 / 43 \mathrm{TAU}\end{array}$ \\
\hline Perlis et al. (2002) & $\begin{array}{l}66 \text { CBT } \\
66 \text { medication } \\
\text { management }\end{array}$ & Blind & DSM-III-R & $\begin{array}{l}\text { DSM-III-R major depression } \\
\text { or increase in symptoms }\end{array}$ & 28 weeks & 28 weeks & $\begin{array}{l}\geqslant 3 \text { episodes in past } \\
2.5 \text { years; most recent } \\
\text { episode chronic; poor } \\
\text { interepisode recovery. } \\
\text { Antidepressant } \\
\text { continued throughout } \\
\text { study }\end{array}$ & $\begin{array}{l}4 / 66 \text { CBT } \\
5 / 66 \text { Control }\end{array}$ \\
\hline $\begin{array}{l}\text { Ma \& Teasdale } \\
\text { (2004) }\end{array}$ & $\begin{array}{l}36 \mathrm{CBT} \\
37 \mathrm{TAU}\end{array}$ & Blind & DSM-IV & DSM-IV major depression & $\begin{array}{l}8 \text { weeks } \\
+2 \text { booster } \\
\text { sessions }\end{array}$ & 1 year & $\begin{array}{l}\geqslant 2 \text { episodes in past } \\
5 \text { years. } \\
\text { All patients off } \\
\text { antidepressants for at } \\
\text { least } 12 \text { weeks before } \\
\text { study entry }\end{array}$ & $\begin{array}{l}14 / 36 \mathrm{CBT} \\
23 / 37 \mathrm{TAU}\end{array}$ \\
\hline Bockting et al. (2005) & $\begin{array}{l}88 \text { group CBT } \\
84 \text { TAU }\end{array}$ & Blind & DSM-IV & DSM-IV major depression & 8 weeks & 2 years & $\begin{array}{l}\text { Rates of antidepressant } \\
\text { treatment did not differ } \\
\text { between groups }\end{array}$ & $\begin{array}{l}49 / 88 \mathrm{CBT} \\
54 / 84 \mathrm{TAU}\end{array}$ \\
\hline \multicolumn{9}{|l|}{ III. Bipolar disorder } \\
\hline Lam et al. (2003) & $\begin{array}{l}51 \mathrm{CBT} \\
52 \mathrm{TAU}\end{array}$ & Blind & DSM-IV & $\begin{array}{l}\text { DSM-IV major depression, } \\
\text { mania or hypomania }\end{array}$ & $\begin{array}{l}6 \text { months } \\
+2 \text { booster } \\
\text { sessions }\end{array}$ & 6 months & $\begin{array}{l}\geqslant 2 \text { episodes in past } \\
2 \text { years or } \geqslant 3 \text { episodes } \\
\text { in past } 5 \text { years. } \\
\text { Patients with residual } \\
\text { symptoms excluded }\end{array}$ & $\begin{array}{l}21 / 51 \mathrm{CBT} \\
36 / 52 \mathrm{TAU}\end{array}$ \\
\hline
\end{tabular}


Table A2 (cont.)

\begin{tabular}{|c|c|c|c|c|c|c|c|c|}
\hline Study & Sample sizes & Blindness & $\begin{array}{l}\text { Diagnostic } \\
\text { criteria }\end{array}$ & Relapse criteria & Duration of CBT & Follow-up & Patient type & Relapse rates \\
\hline Ball et al. (2006) & $\begin{array}{l}25 \mathrm{CBT} \\
27 \mathrm{TAU}\end{array}$ & Blind & DSM-IV & $\begin{array}{l}\text { DSM-IV major depression, mania, } \\
\text { hypomania, mixed state }\end{array}$ & 6 months & 6 months & $\begin{array}{l}\geqslant 1 \text { episode in past } 18 \\
\text { months. } \\
\text { Patients with mild } \\
\text { symptoms included }\end{array}$ & $\begin{array}{l}5 / 25 \mathrm{CBT} \\
9 / 27 \mathrm{TAU}\end{array}$ \\
\hline Scott et al. (2006) & $\begin{array}{l}127 \mathrm{CBT} \\
126 \mathrm{TAU}\end{array}$ & Blind & DSM-IV & $\begin{array}{l}\text { DSM-IV major depression, mania, } \\
\text { hypomania, mixed state }\end{array}$ & $\begin{array}{l}6 \text { months } \\
+2 \text { booster } \\
\text { sessions }\end{array}$ & 12 months & $\begin{array}{l}\geqslant 2 \text { episodes of illness } \\
(1 \text { in past year). } \\
\text { Rapid cyclers excluded. } \\
\text { Patients with mild } \\
\text { symptoms included }\end{array}$ & $\begin{array}{l}67 / 127 \mathrm{CBT} \\
64 / 126 \mathrm{TAU}\end{array}$ \\
\hline $\begin{array}{l}\text { Zaretsky et al. } \\
(2008)\end{array}$ & $\begin{array}{l}40 \text { CBT + psycho- } \\
\text { education } \\
39 \text { TAU + psycho- } \\
\text { education }\end{array}$ & Blind & DSM-IV & $\begin{array}{l}2 \text { weeks of moderate/severe } \\
\text { depressive or } 1 \text { week of } \\
\text { moderate/severe symptoms of } \\
\text { hypomania on daily mood chart } \\
\pm \text { hospitalization }\end{array}$ & 13 weeks & 12 months & $\begin{array}{l}\text { Bipolar I or II, not } \\
\text { currently in full episode }\end{array}$ & $\begin{array}{l}6 / 40 \\
4 / 39\end{array}$ \\
\hline
\end{tabular}

CBT, Cognitive behavioural therapy; TAU, treatment as usual; RDC, Research Diagnostic Criteria.

${ }^{a}$ Numbers refer to patients who showed full or partial recovery (see text). 